\title{
Animal Enhancement, Uplift or Augmentation? Clarifying concepts
}

\author{
Piero Gayozzo
}

\begin{abstract}
Director of Secular Humanist Society of Peru (Sociedad Secular Humanista del Perú - SSH). Founder and Sub-Director of Institute of Extrapolitics and Transhumanism, a research group of SSH. Member of Peruvian Association of Journalists and Science Communicators (Asociación Peruana de Periodistas y Comunicadores de la Ciencia APCIENCIA) and Peruvian Atheist Association -APERAT. Founder and Chief Editor of Future Now Journal (Futuro Hoy).
\end{abstract}

\begin{abstract}
The ethical debate on human enhancement has motivated futurist literature to discuss about animal enhancement too. In this nascent discussion, various concepts that refer to the technological modification of animals are sometimes used indistinctly, including animal enhancement, animal uplift, animal augmentation and animal disenhancement. The purpose of this article is to provide a more precise definition of the abovementioned concepts. For this, the available literature on the debate was reviewed and it was concluded that these terms, although similar, refer to different types of technological modifications.
\end{abstract}

Keywords: Animal enhancement, animal augmentation, animal disenhancement, animal uplift, bioethics, speciesism, transhumanism.

\section{Introduction}

In recent years the ethical debate unleashed by the transhumanist philosophy and, specifically, its focus on human enhancement has been quite prolific (Mercer \& Maher, 2014) (Hansell \& Grassie, 2010) (Bostrom \& Savulescu, 2011). As can be reviewed in futurist literature, this debate has not only opened the doors to discuss about biological evolution control (Cordeiro, 2015) or about the future of human species in a posthuman scenario (Goux-Baudiment, 2014), but also about the effects of advanced technologies on animals, in what is known as animal enhancement (Hauskeller, 2017) (Bateman et al., 2015a) (Thompson, 2008). Although it is possible to indicate that the academic debate on this topic is quite recent, important contributions have already been published, such as Sarah Chan's (2009) defense of animal enhancement as a moral obligation or George Dvorsky's (2008) controversial demand for animal uplift. Also, some book chapters (Grunwald, 2012) (Yeates, 2013) and even entire books (Grandin \& Whiting, 2018) (Bateman et al., 2015a) dedicated exclusively to this topic have been published in recent years.

By focusing on the discussion concerning the animal-technology relationship and the debate in question, it is possible to identify four closely related concepts: animal enhancement, animal uplift, animal augmentation, and animal disenhancement. As indicated by Bateman et al. (2015b), it is important to establish the differences between the technological procedures to which the animals will be subjected, as well as the interests and objectives that underlie those actions. For this reason, in what follows, the previous concepts will be elucidated and clarified, as well as that of animal techno-breeding will be added in order to specify the terms to be used in the debate and contribute to it. First, each concept will be defined based on the available literature. Then, using some of the criteria considered in each concept, a more precise definition will be proposed for each one.

\section{Animal uplift}

A term popularized by science fiction writer David Brin, it implies the technological uplift of non-sentient beings or those with limited cognitive abilities to a level of intelligence comparable to that of humans that allows them to articulate language or use technologies (Encyclopedia of Science Fiction, 2017)(Westfahl, 2005, págs. 850-852). Although it is a resource explored speculatively in science fiction, we can indicate 
that animal uplift is a procedure that aims to elevate the status of the animal from a passive object to a subject with active capacities for changing its environment and direct communication with humans (Moreno, 2020).

Indirectly, animal uplift implies the attempt to achieve that non-human animals overcome the traits that humans share with them, but that we have learned to control or subdue through education and, mainly, through the capacity for abstract reasoning; that is, the overcoming of what we can call "animality". Indeed, as Hauskeller (2017) states, animal uplift is based on a disadvantaged valuation of non-human animals and an interpretation of human being seen as the best animal (anthropocentrism). Those reasons allow us to describe uplift as a procedure to humanize animals, to liberate them from their animality in order to turn them into ex-animals made in the image of human beings and equip them with the necessary skills to recognize us on the same intellectual and communicative level.

For his part, Dvorsky (2008) identifies two types of uplift: cultural and biological. The first is linked to the information that is transmitted intergenerationally between members of the same species, in a non-genetic way; procedure that does not require the organism to be directly modified or altered. In other words, it refers to what can be called cultural selection, and which is present in some great apes, dolphins and, more notably, in humans. Regarding the second, he defines it as the procedure for endowing animals with cognitive and social skills that will allow them to participate in political life and manage their own lives and environments in a better way.

\section{Animal Augmentation}

The idea of animal augmentation arises from the artistic project of James Auger, which, beyond the artistic novelty, is described as a process of inclusion of technologies in animals in order to serve them to overcome their evolutionary deficiencies (Sandhana, 2005).

To better understand this proposal, at least three types of environments must be distinguished: artificial, those in which the human presence predominates; semi-artificial, those in which human activity begins its presence or is sporadic; and natural ones, those in which there is none human activity. Animals have developed abilities for specific environments through evolution. That balance experienced in a natural ecosystem can be directly affected by the interference of human activity, which is not only capable of circumventing animal abilities, but also of affecting their well-being.

Since biological evolution goes slow, it is not possible for animals to adapt to our complex activity, that is why in this context technologies become an ally and an opportunity for them to survive. In this way, animal augmentation is proposed as a solution to the disadvantage of animals living in artificial or semi-artificial environments. In the case of wild animals, animal augmentation would seek to lessen the negative effects of semi-artificial environments on their abilities. With regard to domestic animals, animal augmentation would serve to avoid them further suffering (Auger \& Loizeau, 2000-2008). This last definition, as will be seen later, could be included in the discussion on animal disenhancement, so it is necessary to highlight that it refers to companion animals and not to domesticated ones that are part of the food industry. In a succinct way, animal augmentation would basically consist of technologically helping animals to survive in an environment in which there is an increasing human presence that can affect them (Wired, 2007).

\section{Animal Enhancement}

One of the most recognized definitions for animal enhancement is that of Chan (2009), who defines it as a procedure that:

1) Produces an increase in natural functions or adds new ones.

2) Improve some aspect of the animal for human purposes.

3) It allows a greater fulfillment of the interests of the animal.

Grunwald (2012) reaches to a similar conclusion while defining it. In fact, Grunwald coincides with conditions (1) and (2), but performs a deeper analysis of the concept of "enhancement" and includes 3 
semantic dimensions to understand its nature: the need to establish a point of reference from which something is enhanced; to consider a normative criterion or direction of change, and to verify the measure of change to determine whether or not an enhancement occurred. For this reason, he affirms that unlike concepts such as optimization or improvement, enhancement does not have a final goal, instead it is a modification whose valuation and purpose can vary widely. For example, for uses in the food industry, enhancement could mean to improve the living condition of the animal, to increase production or consumer benefits, among others. In short, for Grunwald (2012, pág. 235) animal enhancement is a procedure in which "Someone enhances something according to a criterion".

This leads him to indicate that, with respect to condition (3) of Chan's definition, it is undeniable that all technological procedure of animal modification includes the impossibility of having an informed consent from the animal and, therefore, is subject to be the man who determines the enhancement criteria. For this reason, Grunwald highlights the role of two predominant ethical approaches in the debate: the utilitarian, linked to human profit, and the advocatory, which imagines the perspective and interests of the animal from the human lens.

Ferrari (2015) agrees on this, since she shows that in the debate, animal enhancement is understood indistinctly as procedures for reducing and improving animal skills, as well as taking into account human and animal interests simultaneously. For this reason, Ferrari rejects Chan's condition (2) and affirms that the approach of animal enhancement advocates who omit criticism on animal experimentation or accept Chan's condition (2), far from referring to animal enhancement, actually promotes a form of human-centered paternalism (humans know what is best and useful for animals, even if they need technologies or not), which she called Technovisionary animal welfarism.

Another perspective on animal enhancement is that of Yeates (2013), which may be compatible with the previous one, but highlights that, due to the variety of procedures and interests involved, animal enhancement is a broad concept whose use may be restricted to some cases and, to the extent as possible, should be used as an umbrella term.

\section{Animal disenhancement and animal techno-breeding}

Until now, it has not been possible to clearly define animal enhancement because, as has been analyzed, there is a discrepancy with respect to the criterion (3) offered by Chan. What would be the reason to consider as animal enhancement a procedure in which only human utility is sought? There is a category for procedures that improve the living conditions of the animals through the technological decrease of their abilities (blind hens to resist life on the farm or non-sentient animals for the food industry) in favor of increasing human utility, Ferrari (2015) calls them animal disenhancement.

The conditions to define animal disenhancement according to Ferrari are basically three:

(1) It improves the living conditions of animals' life through the technological decrease of their abilities.

(2) Responds to human utility.

(3) It tries to solve moral dilemmas about animal captivity.

The truth is that it is not necessary to resort to advanced technologies to modify animal characteristics at human's will and profit. Our species has selectively bred a large number of animal and plant species, managing to reduce or increase some characteristics or behaviors and has even increased the usefulness and productivity of animal resources, e. g. making some species more suitable for hunting, security, and transportation support, or increasing the production of meat and dairy products. Following this approach, the French political scientist Guillaume Faye (2010) proposes that biotechnologies must be used to improve animal productivity. The latter is what we will call animal techno-breeding, since, unlike animal disenhancement, it does not necessarily meet conditions (1) and (3). Animal techno-breeding has the same 
objectives as selective breeding, but reducing the time it takes for generational breeding through the application of advanced biotechnologies such as genetic engineering or similar techniques.

\section{Clarifying concepts}

The existence of well-defined terms such as animal uplift or animal augmentation has been exposed, but the main concept of the debate, that of animal enhancement, encounters difficulties and the discrepancies that exist around the proposed meanings open the doors to include new terms that refer more accurately to some set of animal technological modification practices. Therefore, an appropriate definition of the concepts developed in the article will be offered based on 5 criteria (see Figure 1): who is the beneficiary (animals or human beings), what is the degree of benefit (direct or indirect), the nature of their objective (to increase survival or reduce suffering), the purpose, the underlying worldview and the ethical approach from which they are elaborated.

\begin{tabular}{|c|c|c|c|c|c|c|c|c|}
\hline \multirow{2}{*}{ Type } & \multirow{2}{*}{\multicolumn{2}{|c|}{ Sub-type }} & \multirow{3}{*}{$\begin{array}{l}\begin{array}{l}\text { Beneficiary } \\
\text { (Degree) }\end{array} \\
\begin{array}{l}\text { Animals } \\
\text { (debatable) }\end{array} \\
\end{array}$} & \multicolumn{2}{|l|}{ Objective } & \multirow{2}{*}{ Purpose } & \multirow{2}{*}{$\begin{array}{l}\text { Underlying } \\
\text { Worldview }\end{array}$} & \multirow{2}{*}{$\begin{array}{l}\text { Ethical } \\
\text { Approach }\end{array}$} \\
\hline & & & & $\begin{array}{l}\text { Increase } \\
\text { survival }\end{array}$ & $\begin{array}{l}\text { Reduce } \\
\text { suffering }\end{array}$ & & & \\
\hline \multirow{3}{*}{$\begin{array}{l}\text { Animal } \\
\text { Enhancement }\end{array}$} & \multirow{2}{*}{$\begin{array}{l}\text { Animal } \\
\text { Uplift }\end{array}$} & $\begin{array}{l}\text { Anthropocentric } \\
\text { Animal Uplift }\end{array}$ & & Debatable & Debatable & $\begin{array}{l}\text { Humanize } \\
\text { animals }\end{array}$ & $\begin{array}{l}\text { Anthropocentric } \\
\text { view of evolution }\end{array}$ & $\begin{array}{l}\text { Advocatory/ } \\
\text { Utilitarian }\end{array}$ \\
\hline & & $\begin{array}{l}\text { Transhumanist } \\
\text { Animal Uplift }\end{array}$ & $\begin{array}{l}\text { Animal } \\
\text { (directly) }\end{array}$ & Yes & Yes & $\begin{array}{l}\text { Promotion of } \\
\text { conscious life }\end{array}$ & Transhumanist & $\begin{array}{l}\text { Anti- } \\
\text { speciecist }\end{array}$ \\
\hline & \multicolumn{2}{|c|}{ Animal Augmentation } & $\begin{array}{l}\text { Animals } \\
\text { (directly) }\end{array}$ & Yes & Yes & $\begin{array}{l}\text { Allow } \\
\text { animals to } \\
\text { compete in } \\
\text { artificial } \\
\text { environments }\end{array}$ & $\begin{array}{l}\text { Techno- } \\
\text { paternalism }\end{array}$ & $\begin{array}{l}\text { Anti- } \\
\text { speciesist }\end{array}$ \\
\hline \multirow{2}{*}{$\begin{array}{l}\text { Animal } \\
\text { Techno- } \\
\text { modification }\end{array}$} & \multicolumn{2}{|c|}{ Animal Techno-Breeding } & $\begin{array}{l}\text { Humans } \\
\text { (mainly). } \\
\text { Effects on } \\
\text { animals are } \\
\text { not priority. }\end{array}$ & $\begin{array}{l}\text { Not its } \\
\text { main } \\
\text { objective }\end{array}$ & $\begin{array}{l}\text { Not its } \\
\text { main } \\
\text { objective }\end{array}$ & $\begin{array}{l}\text { Increase } \\
\text { productivity }\end{array}$ & $\begin{array}{l}\text { Speciesist- } \\
\text { Anthropocentric }\end{array}$ & Utilitarian \\
\hline & \multicolumn{2}{|c|}{ Animal Disenhancement } & $\begin{array}{l}\text { Humans } \\
\text { (mainly). } \\
\text { Animals } \\
\text { (indirectly). }\end{array}$ & Yes & Yes & $\begin{array}{l}\text { Reduce } \\
\text { human moral } \\
\text { conflicts } \\
\text { about animal } \\
\text { breeding }\end{array}$ & $\begin{array}{l}\text { Tecno- } \\
\text { paternalism } \\
\text { welfarism }\end{array}$ & $\begin{array}{l}\text { Advocatory/ } \\
\text { Utilitarian }\end{array}$ \\
\hline
\end{tabular}

Figure 1. Definition of the concepts used in the debate on animal enhancement.

Source: Own elaboration.

\section{Animal enhancement}

In the case of animal enhancement, Yeates (2013) is right when pointing out that it is a broad concept, but far from avoiding its use and including some of the previous procedures into it, we will point it out as those procedures that aim to modify animals and have them as main beneficiaries. We will include animal uplift and animal augmentation as forms of animal enhancement.

\section{Animal Uplift}

Technological procedure in which the cognitive capacities of an animal or animal species are increased. The benefit could be discussed between two different degrees: direct, if it benefits the animal, or indirect, if the procedure actually seeks to benefit human beings. This difference in degrees invites us to distinguish two variants of animal uplift: the transhumanist and the anthropocentric.

The animal uplift guided by a transhumanist worldview implies the acceptance of an anti-speciesist ethical approach, that is, it does not discriminate against non-human animals. As a consequence of its transhumanist approach, this variation of animal uplift would seek the promotion of conscious life and would establish the animal as its direct beneficiary since its objectives would be to increase animals' chances of survival and reduce their suffering through the technological improvement of their cognitive abilities. This is the case of transhumanist author James Hughes (2004) who proposes that uplifts will have the same citizenship status of 
transhumans or cyborgs and that animals might be uplifted only if the procedures does not include any downsides for them.

On the other hand, if animal uplift is guided by an anthropocentric worldview of evolution, that is, its purpose is to humanize animals, the definition of the beneficiary becomes a debatable issue. On the one hand, it could have a utilitarian ethical approach, case in which it could be seeking only to know the consequences of a humanized animal or to study the crossing of borders between the animal and the complex human social organization. In this case, the direct beneficiary would be human being and the increase in survival or reduction of animal suffering would be collateral and non-priority effects. If animal uplift is guided by an advocatory ethical approach, one might wonder, how much would it benefit an animal to subject it to a process of humanization? For this reason, it could be debated whether this intervention really increases their well-being or reduces their suffering, however, it is not a sufficient reason not to consider animal uplift as a type of animal enhancement.

\section{Animal Augmentation}

It was indicated that animal augmentation is a procedure for wild and domestic companion animals. The reason for this is that the search for the direct benefit of animals in the food industry would be to remove them from it and would require an abolitionist perspective. However, as this debate is not the central theme of the article, we will stick it to the definition of animal augmentation, a purpose for which we coincide with Auger (Wired, 2007) in that it is all technological procedure that seeks the survival of animals in environments in which there is an increasing possibility of negative impact as a consequence of human presence. But other conditions are implicit in the animal augmentation, in this case, the procedure is guided by a techno-paternalistic worldview. As Ferrari (2015) indicates, not all paternalism is negative, in this case techno-paternalistic worldview of animal augmentation is based in an anti-speciesist approach that identifies animals as the direct beneficiaries. According to it, animal augmentation is a call to use technologies to allow animals to compete in artificial environments and accelerate their adaptation with the clear objective to increase their survival abilities and to reduce their suffering.

\section{Animal technological modification}

On the other hand, animal disenhancement and animal techno-breeding will be defined as procedures that have in common that the main beneficiary is the human being, for this reason they will be grouped within the concept of animal technological modification.

\section{Animal techno-breeding}

Animal techno-breeding is any technological procedure that modifies animals, but has the human being as its main beneficiary. Its objective is neither to increase the survival nor to reduce the suffering of animals, on the contrary, its purpose is solely to increase the productivity of animal resources mainly in general industry. This type of procedure is guided by an anthropocentric speciesist worldview that considers animals as mere tools and whose ethical approach is clearly utilitarian.

\section{Animal Disenhancement}

Animal disenhancement is any technological procedure that reduces animals' abilities and, as contradictory it could be seen, aims to indirectly benefit them. That definition is enough to affirm that animal disenhancement have been designed mainly to benefit human beings. Although the modifications seek to increase animal survival or reduce their suffering, animal disenhancement apply only to animals that are part of the food industry, since its purpose is to reduce moral conflicts that arise in the community from overcrowded conditions and treatment to which some animal species are subjected. That is why we can say that this procedure is guided by a utilitarian and advocatory ethical approach supported by a technopaternalistic welfare worldview.

\section{Conclusions}

Animal enhancement is a debate that has just started, so special attention should be paid to the concepts involved in it. As has been described, there are several terms that, in principle, could be used indistinctly; however, when analyzing them in greater detail, the need for other variables to be included for their correct definition becomes evident. In this article it was seen that the main difference between animal enhancement 
and animal technological modifications is that, despite the fact that both accept technological interventions in animals, the former has the animal as its main beneficiary, while the latter benefits mainly human beings. Even when adding other variables, it is distinguished that within each set of procedures there are differences. In the case of animal enhancement, this includes animal uplift and animal augmentation; while within the animal technological modifications we can distinguish animal disenhancement and animal techno-breeding. It is expected that this article could contribute to the debate on animal enhancement and to reflections on the future of advanced technological applications in animals.

\section{References}

1. Auger, J., \& Loizeau, J. (2000-2008). Projects-Augmented Animals. http://www.augerloizeau.com/_oldsite/projects/augani/pro_augani.html

2. Bateman, S., Gayon, J., Allouche, S., Goffette, J., \& Marzano, M. (2015). Introduction. En S. Bateman, J. Gayon, S. Allouche, J. Goffette, \& M. Marzano, Inquiring into Animal Enhancement: Model or Countermodel of Human Enhancement? (págs. 1-12). Palgrave Macmillan.

3. Bateman, S., Gayon, J., Allouche, S., Goffette, J., \& Marzano, M. (2015a). Inquiring into Animal Enhancement. Model or Countermodel of Human Enhancement. Palgrave Macmillan.

4. Bostrom, N., \& Savulescu, J. (2011). Human Enhancement. Oxford University Press.

5. Chan, S. (2009). Should we enhance animals? Journal of Medical Ethics, 35(11), 678-683. https://doi.org/0.1136/jme.2009.029512

6. Cordeiro, J. (2015). The Boundaries of the Human: From Humanism to Transhumanism. World Futures Review, 6(3), 231-239. https://doi.org/10.1177/1946756714555916

7. Dvorsky, G. (2008). All Together Now: Developmental and ethical considerations for biologically uplifting nonhuman animals. Journal of Evolution \& Technology, 18(1), 129-142.

8. Encyclopedia of Science Fiction. (22 de Noviembre de 2017). Uplift. http://www.sfencyclopedia.com/entry/uplift

9. Faye, G. (2010). Archeofuturism. London: Arktos Media Ltd.

10. Ferrari, A. (2015). Animal Enhancement: Technovisionary Paternalism and the Colonisation of Nature. En S. Bateman, J. Gayon, S. Allouche, J. Goffette, \& M. Marzano, Inquiring into Animal Enhancement: Model or Countermodel of Human Enhancement? (págs. 13-33). Palgrave Macmillan.

11. Goux-Baudiment, F. (2014). Future Human Evolution: Alternative Visions of Tomorrow. World Future Review, 6(3), 293-302. doi:https://doi.org/10.1177/1946756714555920

12. Grandin, T., \& Whiting, M. (2018). Are We Pushing Animals to Their Biological Limits? Welfare and Ethical Implications. CABI.

13. Grunwald, A. (2012). Animal Enhancement. En A. Grunwald, Responsible Nanobiotechnology. Philosophy and Ethics (págs. 227-250). Pan Standford Publishing.

14. Hansell, G. R., \& Grassie, W. (2010). H+/- Transhumanism and Its Critics. Philadelphia: Metanexus.

15. Hauskeller, M. (2017). How to Become a Post-Dog: Animals in Transhumanism. Between the Species, 20(1).

16. Hughes, J. (2004). Citizen Cyborg. United States: Westview Press.

17. Mercer, C., \& Maher, D. F. (2014). Transhumanism and The Body. New York: Palgrave Macmillan.

18. Moreno, R. M. (2020). Animal Representation in Recent Anglophone Science Fiction: Uplifting and Anthropomorphism in Nnedi Okorafor's "Lagoon" and Adam Roberts's "Bête". OCeánide, 12, 7883. https://doi.org/10.37668/oceanide.v12i.28

19. Sandhana, L. (05 de Marzo de 2005). Augmenting the Animal Kingdom. https://www.wired.com/2005/05/augmenting-the-animal-kingdom/

20. Thompson, P. B. (2008). The Opposite of Human Enhancement: Nanotechnology. Nanoethics, 2(3), 305-316. https://doi.org/10.1007/s11569-008-0052-9

21. Westfahl, G. (2005). The Greenwood Encyclopedia of Science Fiction and Fantasy. Themes, Works and Wonders. Greenwood Press.

22. Wired. (01 de Septiembre de 2007). James Auger's Augmented Animals. https://www.wired.com/2007/01/james-augers-au/ 
Piero Gayozzo et. al/ Animal Enhancement, Uplift or Augmentation? Clarifying concepts

23. Yeates, J. (2013). The Ethics of Animal Enhancement. En C. M. Wathes, S. A. Corr, S. A. May, S. P. McCulloch, \& M. C. Whiting, Veterinary \& Animal Ethics. Proceedings of the First International Conference on Veterinary and Animal Ethics, September 2011 (págs. 113-132). Wiley-Blackwell. 